\title{
Nilai Lokal Krik Salamat sebagai Asas dalam Pembangunan Hukum
}

\author{
Lahmuddin Zuhri \\ Dosen Fakultas Hukum Universitas Samawa Sumbawa Besar- NTB \\ lahmuddinzuhri@yahoo.com
}

\begin{abstract}
Abtrak
Perpaduan nilai kearifan Lokal dan dan Pancasila sebagai acuan pembangunan hukum yang krakter, mengingat begitu besar dan majemuknya negara Indonesia. Tiap-tiap daerah mempunyai budaya dan agama yang terefleksikan pada kebijakan pembangunan. Kebijakan pembangunan yang terbentuk dari aspirasi masyarakat (botton up) akan memberikan kenyamanan bagi masyarakat dalam menyelenggarakan kehidupan yang berlandaskan nilainilai moralitas berkeadilan. Pembangunan hukum merupakan alat untuk melakukan perubahan sosial, yang mengedepankan nilai lokal yang dilaksanakan secara demokrasi dengan mekanisme permusyawaratan dengan asas rasionalitas dan keadilan sosial, asas berkelanjutan, serta asas persamaan hak. Nilai Kerik Salamat masyarakat Sumbawa, memandang bahwa kekuasaan itu datang dari Tuhan yang harus dipertangungjawabkan secara transparan, kepada Tuhan dan manusia.
\end{abstract}

\section{Kata Kunci: Nilai Lokal, Asas hukum, Pembangunan Hukum}

\section{Pendahuluan}

Proses pembangunan hukum yang dilaksanakan guna mendapatkan bentuk perubahan sosial yang tepat adalah suatu upaya yang menentukan konsep penentuan nasib suatu bangsa. Masyarakat dengan pembangunan butuh penentuan nasih sendiri, kebutuhan dasar manusia, kelangsungan hidup (sustainability) dan pembangunan berdasarkan pertimbangan lain yang bersifat lokal (mengedepankan kebutuhan dan nilai-nilai lokal). Perlu dipikirkan pembangunan alternatif, dengan mengedepankan kekuatan lokal (baik kekuatan sejarah masyarakat lokal, ekologi dan kebudayaan mereka sendiri). Terkai dengan pembangunan kareakter bangsa, diperlukan suatu pendekaran alternatif dengan memposisikan masyarakat dan nilai lokalnya sebagai pilar utama dalam pembangunan suatu bangsa, bangsa Indonesia dengan keanekaragaman nilai dan budaya, harus memposisikan nilai lokal tersebut sebagai penopang nilai dan krakter bangsa. 
Pembangunan krakter, harus diselaraskan dengan nilai kearifan lokal Kerik Slamat masyarakat Sumbawa. Krik Salamat merupakan serangkaan nilai-nilai yang mengandung semangat kerja, semangat menjaga kelestarian lingkungan (alam), semangat kekeluargaan-kebersamaan, semangat kegotong-royongan, serta yang tidak kala penting semangat Ketauhidan. Masyarakat Sumbawa memaknai "krik slamat" sebagai limpahan anugerah dan keselamatan. Istilah krik slamat merupakan gabungan dari dua istilah, yang tiap istilah mempunyai pengertian tersendiri, yaitu paduan dari istilah limpahan anugerah (krik) dan istilah keselamatan (salamat (Sanapiah S Faisal, 1999: 194).

Anugerah (krik) di sini bukan hanya materi tetapi hak-hak yang inmateri juga termasuk di dalamnya, kerena masyarakakat Sumbawa memandang kebahagiaan tidak hanya datang dari materi, tetapi ketenangan jiwa yang juga bagian terbesar dari anugerah Tuhan tersebut, pangkat/jabatan dan kehormatan juga disebut memperoleh anugerah.
Pembangunan hukum menuju pembentukan kareakter bangsa, dipandang perlu mendayagunakan nilai lokal sebagai asas hukum, karena bangsa Indonesia dengan keanekaragamannya, harus memposisikan nilai lokal sebagai alternative penguat nilai dan krakter bangsa. Sehingga perlu pengkajian yang luar biasa, dengan memahami berbagai keragaman serta karakter budaya, adat, agama dan lainlainnya. Hal ini mengingat begitu besar dan majemuknya negara Indonesia. Tiap-tiap daerah mempunyai budaya dan agama yang terefleksikan pada kebijakan pembangunan. Kebijakan pembangunan yang terbentuk dari aspirasi masyarakat (botton up) akan memberikan kenyamanan bagi masyarakat itu sendiri.

Hal ini berdampak pada proses sosialisasi dan internalisasi nilai akan mudah, sebab masyarakat merasa ikut memilikinya. Karena itu masyarakat akan ikut menjaga dan melaksanakannya dengan penuh kesadarannya sendiri. Berbeda bila hukum terbentuk dari aspirasi top down (dari penguasa) sehingga 
memerlukan sosialisasi, juga memerlukan pengawasan yang ekstra, sebab belum tentu masyarakat sebagai pengguna hukum mengerti, memahami dan mau melaksanakannya. Sebab tidak mustahil terbentuknya hukum yang top down berbeda dengan kepentingan masyarakat. Sebagaimana diketahui terbentuknya undang-undang maupun Peraturan Daerah merupakan hasil dari proses politik dan proses politik tidak lepas dari beberapa kepentingan.

Nilai yang terkandung dalam hukum dengan nilai-nilai masyarakat lokal kerap sekali terjadi perbedaan yang berakibat sulitnya pemahaman makna dan maksud hukum nasional oleh masyarakat lokal, hal ini terjadi karena sudut pandang dan nilai dasar penyusunan hukum tampaknya berbeda antara legislator dengan masyarakat serta kurangnya paran pemegang kebijakan melakukan penelitian dan survei, uji publik terhadap nilai-nilai lokal, kebutuhan-kebutuhan lokal terutama masyarakat yang secara geografis jauh dan mungkin tidak terjangkau oleh pengendali kebijakkan, hasilnya hukum dibuat terasa tidak bermakna dan bermanfaat bagi sebagian besar rakyat tersebut.

Setiap kebudayaan memiliki gambaran perilaku yang layak dan tidak layak dilakukan, gambaran perilaku tersebut kemudian diformulasikan secara konkret dalam berbagai tatanan hidup manusia melahirkan norma, dan hukum berada didalamnya disamping norma kesopanan, kesusilaan dan keagamaan. Jika demikian, hukum merupakan refleksi tata perilaku komunitas tertentu yang bersifat teoritorial, khas dan khusus, dalam arti hukum masyarakat satu berbeda dengan yang lainnya, oleh karena itu pembentukan hukum, penerapan hukum harus berdasarkan realitas sosial mengingat hukum bukan saja sebagai formalisasi dan konkretitasi perilaku masyarakat dalam bentuk deretan pasal-pasal melainkan juga jiwa masyarakat (Volkgelst) itu, serta hukum itu dibuat bukan untuk penguasa tetapi untuk kepentingan masyarakat. Oleh 
karena itu mengambil kebijakan dalam hal ini dalam memformulasikan kebijakan harus banyak-banyak mengaca, membaca dan menganalisis realitas sosial dan nilai tempat kebijakan itu diterapkan.

Tulisan ini ingin mengulas tentang asas nilai lokal dalam pembangunan hukum, kemudian dari itu, ingin membuat model bahwa nilai lokal dapat dijadikan asas dalam pembangunan hukum yang adil dan bermoral, tulusan ini mengunakan kajian yuridis-antropologis (Budiono Kosumohamidjoyo, 2000: 45), sehingga dapat mengali asas hukum dari nilai lokal dalam keseharian masyarakat (Valerina Jaqualine Leonore Kriekhoff, 1991: 57). Karena Wolfgang Friedmann menjelaskan bahwa pada dasarnya norma hukum selalu diambil dari fakta-fakta sosial yang ada dalam keyakinan asosiasi rakyat. Perlindungan yang dilakukan oleh negara dengan menggunakan hukum yang mengekspresikan sifat memaksa seyogyanya tidak perlu dilakukan (Wolfang Friedmann, 1996: 105).
Nilai Kearifan Lokal Kerik Salamat $=$ Pancasila

Karakter yang terkandung dalam nilai kearifan lokal kerik salamat masyarakat Sumbawa dalam pembangunan hukum yang bermoral yang tujuan akhirrnya dapat membangun karakter bangsa, yang dalam tulisan ini alan mengulas Nilai Spiritual dan Keagamaan Tau Samawa. Ketuhanan dalam kerangka Pancasila mencerminkan komitmen etis bangsa Indonesia untuk menyelenggarakan kehidupan publik-pilitik yang berlandaskan nilai-nilai moralitas dan budi pekerti yang luhur. Menurut penjelasan Undang-Undang Dasar Negara Rapublik Indonesia 1945, disebutkan dalam "Pembukuan UUD" ialah “ negara berdasar atas Ketuhanan Yang Maha Esa menurut dasar kemanusiaan yang adil dan beradab". Berdasarkan pokok pikiran ini, UUD "harus mengandung isi yang mewajibkan Pemerintah dan lain-lain penyelenggara negara, untuk memelihara budi-pekerti kemanusiaan yang luhur dan memegang teguh cita-cita moral rakyat yang luhur". 
Dalam mengamalkan komitmen etis ketuhanan ini, Pancasila harus didudukkan secara proporsional, bahwa ia bukanlah agama (sesungguhnya) yang berpretensi mengatur sistem keyakinan, sistem peribadatan, sistem norma, dan identitas keagamaan dalam ranah privat dan ranah komunitas agama masing-masing Ketuhanan dalam kerangka Pancasila menyerupai konsepsi "agama sipil" (civicreligion), yang bisa melibatkan nilainilai moral universal agama-agama, namun juga secara jelas dapat dibedakan dari agama. Pretensinya adalah bagaimana menjadikan nilainilai moral Ketuhanan sebagai landasan pengelolaan kehidupan publik-politik dalam konteks masyarakat multikultur-multiagama, tanpa menjadikan salah satu agama (unsur keagamaan) mendikte negara.

Ketuhanan dalam kerangka Pancasila merupakan usaha pencarian titik temu dalam semangat gotong-royong untuk menyediakan landasan moral yang kuat bagi kehidupan politik berdasarkan moralitas Ketuhanan. Dalam kerangka pencarian titik-temu ini,
Indonesia bukanlah negara sekuler yang ekstrim, yang berpretensi menyudutkan agama ke ruang privat karena sila pertama Pancasila (sebagai konsensus publik) jelasjelas menghendaki agar nilai-nilai Ketuhanan mendasari kehidupan publik-politik. Negara juga diharapkan melindungi dan mendukung pengembangan kehidupan beragama sebagai wahana untuk menyuburkan nilai etis dalam kehidupan publik. Namun demikian, Pancasila pun tidak menghendaki perwujudan negara agama, karena, hal itu akan membawa tirani keagamaan yang mematikan pluralitas kebangsaan, dan menjadikan pengikut agama lain sebagai warga negara kelas dua.

Proposisi bahwa "Indonesia bukan negara sekuler dan bukan negara agama" ini memperoleh kontekstualisasinya dalam konsepsi "diferensiasi”. Sebagai jalan tengah antara "fusi" dan "separasi", para pendiri bangsa menawarkan konsepsi “diferensiasi” yang maju (Wolfang Friedmann, 1996 111). Dalam kehadiran Islam sebagai agama mayoritas, setiap agama secara 
prinsip diperlukan setara dengan tidak menjadikan Islam sebagai agama negara. Menyerupai Jerman, dalam praktik kebijakan administrasi negara, memang ada beberapa agama yang diakui sebagai agama resmi negara (Islam, Protestan, Katolik, Hindu, Budha, dan dalam perkembangan kemudian, barangkali juga Khong $\mathrm{Hu} \mathrm{Cu}$ ), tetapi secara konstitusional agama/ keyakinan lain juga memperoleh jaminan kebebasan.

Berdasarkan pasal 29 Ayat 2 UUDN RI 1945, "Negara menjamin kemerdekaan tiap-tiap penduduk untuk memeluk agamanya masingmasing dan untuk beribadat menurut agamanya dan kepercayaannya itu, bahkan kebebasan beragama sudah lama mewarnai konstitusi kita dalam pasal 18 Konstitusi RIS dan UUDS 1950 bahkan telah disebutkan tentang jaminan kebebasan "keinsyafan batin dan pikiran". Kebebasan juga diberikan kepada keyakinan kepercayaan lain, seperti kepercayaan agnostik (agnosticism).

Lebih dari itu, kepedulian Pancasila lebih tertuju pada moralitas publik, tidak mencampuri moralitas (keyakinan) pribadi. Oleh karena itu, dalam kerangka Ketuhanan menurut Pancasila, boleh saja seseorang secara pribadi tidak memeluk agama formal (sebagai agonostik atau bahkan atheis). Akan tetapi, dalam kehidupan publiknya harus tetap menghormati nilai-nilai Ketuhanankeagamaan seperti dikehendaki Pancasila berdasarkan hasil kesepakatan konstitusional, sehingga tidak diperkenankan menyebarkan propaganda untuk menolak atau membenci agama.

Diferensiasi fungsi antara institusi agama dan negara, bisa mundukung upaya penyehatan kehidupan masyarakat. Tidak ada negara beradab tanpa ditopang oleh masyarakat yang juga beradab, dan demikian pula sebaliknya. Ungkapan Mochtar Pabottingi yang sangat menarik untuk direnungkan, bahwa kita memerlukan kehidupan agama yang menghormati mekanisme dan kebajikan demokrasi dan kita memerlukan demokrasi yang menghargai religiusitas, amanah dengan penuh kebajikan dari agama (M. Pobattingi, 1998: 8). 
Ketuhanan menjadi dasar negara Indonesia yang kemudian dijadikan salah satu landasan pengelolaan ruang publik-politik, sehingga hubungan antara nilai-nilai keagamaan dengan kemajuan suatu bangsa sangat erat, hal ini bisa dilihat secara historis agama-agama telah menyejarah dalam perkembangan masyarakat Nusantara dan menjadi bagian penting dalam perjuangan dan pembentukan Indonesia sebagai negara-bangsa. Selebihnya, sejarah jatuh bangunnya peradaban dan bangsa-bangsa di muka bumi mengindikasikan signifikansi peran agama. Hal ini senada dengan apa yang dikemukakan oleh Huntington bahwa goegrafis peradaban yang mampu bertahan adalah geografis peradaban yang berbasis agama/ketuhanan.

Apa yang disampaikan oleh Huntington tersebut, memiliki metode dan sistem yang kuat, yaitu adanya keseimbangan dalam negara, Negara madinah pernah mencontohkan hal tersebut, yang pada dasarnya dikembangkan dalam sistem ketatanegaraan atau pemerintahan Islam ketika masa pemerintahan Rasulullah SAW. Keseimbangan individu, masyarakat, penguasa, yang dikontrol oleh kehendak Illahiah. Kesemuanya mengandung beberapa prinsip sebagai berikut: Prinsip umat, bahwa orang-orang mukmin adalah umat yang satu, tidak termasuk golongan lain, orang-orang Yahudi dan sekutunya adalah satu umat dengan orang mukmin; Prinsip persatuan dan persaudaraan, yakni persatuan dan persaudaraan seagama maupun persatuan dan persaudaraan sosial, atau persatuan dan persaudaraan kemanusiaan; Prinsip persamaan, yaitu pengakuan hak-hak yang sama antara kaum muslimin dan bukan muslim; Prinsip kebebasan, Islam memberikan kebebasan dalam banyak hal untuk terpeliharanya masyarakat yang sangat pluralistik; Prinsip hubungan antar pemeluk agama; Pemeluk agama baik Islam atau di luar Islam pada dasarnya wajib menjalin hubungan baik dalam berbagai hal; Prinsip pertahanan, kedaulatan dari berbagai ancaman musuh, dan menciptakan rasa aman kepada seluruh warga; Prinsip hidup bertetangga, orang yang mendapat 
perlindungan memperoleh hak-hak dan kewajiban yang sama dengan pelindungnya; Prinsip tolong menolong, membela yang lemah dan teraniaya; sebagai aktualisasi adanya kebersamaan dan persahabatan yang harmonis; Prinsip perdamaian, perdamaian diantara komunitas muslim, juga perdamaian muslim dengan komunitas lainnya, sebagai implementasi bahwa Islam adalah agama perdamaian; Prinsip musyawarah, adanya kesepakatan dan dapat diterima substansinya oleh semua orang yang mengadakan perjanjian; Prinsip keadilan, perlakuan adil harus diberlakukan pada muslim atau non muslim; Prinsip pelaksanaan hukum, Pelaksanaan hukum yang merupakan konsekuensi dari penerimaan terhadap substansi (isi) Konstitusi Medinah sebagai perjanjian yang disepakati dan ditandatangani oleh seluruh kelompok masyarakat; Prinsip kepemimpinan, yaitu posisi Rasulullah SAW, sebagai pemimpin umat juga pemimpin masyarakat yang terdiri dari banyak suku dan agama; Prinsip ketaqwaan, sebuah prinsip hubungan yang bersifat horisontal dan vertikal dalam Islam (Dedy Ismatullah, 2008: 158).

Nilai kearifan lokal Kerik Salamat masyarakat Sumbawa, apabila dikaitkan dengan Pancasila sebagai sumber nilai, sehingga penempatan asas ketuhanan dalam membangun kerakter bangsa adalah sesuatu keharusan, hal ini didasari pada keseharian masyarakat Sumbawa yang mempatkan nilainilia ketauhidan dan Islam sebagai pedoman utama dalam membangun budaya dan peradaban tana Samawa (tanah/daerah Sumbawa).

Penulis melihat fungsi Islam dalam ranah kelestarian lingkungan sesuai dengan asas maslahah dalam hal ini bagi kebaikan dan kemanfaatan bersama. Budaya Sumbawa melihat dan memanfaatkan tanah (sawah/ladang), sehingga dalam pengelolaannya mendapat nilai manfaat bagi kebaikan bersama masyarakat Sumbawa. Bertolak dari Teori Maqasid al-Syari'ah, dalam Budaya Sumbawa dengan filosofis Kerik Salamat yang bertujuan menjaga eksistensi komunitas, eksistensi kelestarian alam, yang kesemua itu adalah untuk 
kemanfaatan bersama, guna mendapat keberkahan dan bermanfaat bagi kebutuhan hidup masyarakat Sumbawa.

Budaya dan agama dalam masyarakat Sumbawa memiliki makna yang sangat penting, yang oleh masyarakat Sumbawa digunakan sebagai pedoman hidup, dalam konteks adat dan budaya ('urf) juga merupakan sebagai salah satu sumber hukum masyarakat Sumbawa. Islam berpandangan bahwa adat dapat menjadi dasar penetapan hukum dengan perasyarat adat tersebut tidak bertentangan dengan Al-Quran dan Sunah, dengan syarat: 1) Adat tersebut harus secara umum dipraktikkan oleh masyarakat atau sebagian tertentu dari masyarakat; 2) Adat harus menjadi kebiasaan pada saat ditetapkan sebagai rujukan hukum; 3) Adat batal tatkala bertentangan dengan sumber utama hukum Islam (AlQur'an dan Al-hadist); 4) Jika terjadi perselisihan, adat akan diterima sebagai sumber hukum jika tidak ada pihak yang menolak adat tersebut.

Masyarakat Sumbawa dengan filosofis "Kerik Salamat, Tau ke
Tana Samawa", memadukan nilai budaya (adat) dengan hukum Islam dalam makna ada pertalian yang utuh antara adat Sumbawa dengan hukum Islam, sehingga kedua sistem hukum itu telah lama berlangsung dalam masyarakat dan budaya Sumbawa, dalam pernyataan resmi Lambaga Adat Tama Samawa (LATS) Adat tau samawa (masyarakat Sumbawa) adalah Adat barenti ko syara' syara' barenti ko Kitabullah, ini mengandung makna bahwa masyarakat Sumbawa, memelihara (memegang teguh) agama, maka secara otomatis juga memelihara (memegang teguh) adat, begitu pula sebaliknya, memilihara agama mengandung arti memelihara alam dan seisinya, dalam konteks keislaman bahwa manusia ditakdirkan untuk menjadi khalifa, yang berkewajiban mengelola dan memakmurkan bumi (alam semesta) secara bertangung jawab. Sehingga setiap kegiatan dan aktivitas tau samawa (masyarakat/orang Sumbawa) atau siapapun yang berada pada tana samawa (wilayah Sumbawa) harus dilaksanakan dengan mengedepankan adat-istiadat 
dan nilai agama tau samawa (agama orang Sumbawa).

Hukum Islam dengan hukum adat dan budaya Sumbawa tidak dapat dipisahkan. Tradisi masyarakat Sumbawa dalam bentuk budaya dan hukum adat dalam bahasan kajian Islam disebut dengan 'Urf haruslah yang sesuai dengan kaidah, sehingga adat tersebut dapat dijadikan sumber hukum Islam, misalnya budaya dan adat Sumbawa yang memuliakan lingkungan (tanah), yang dalam setiap aktivitas sehari-hari mereka selalu berinteraksi dengan tanah, karena tanah adalah aset dan sarana memenuhi kebutuhan mereka, baik untuk bertani maupun sarana tempat melepas (memelihara) ternak, untuk pemeliharaan lingkungan (tanah/ekologi) manjadi hal yang sangat penting bagi masyarakat Sumbawa.

$\begin{array}{rr}\text { Pentingnya } & \text { perlindungan } \\ \text { ekologi }\end{array}$
(lingkungan/sawah/ladang) yang ada di kabupaten Sumbawa dapat ditinjau berdasarkan instrumen maqasid alsyariah yaitu jaminan perlindungan terhadap lingkungan hidup atau yang disebut oleh Ali Yafie dengan istilah hifdzu al-bi'ah (Ali Yafie, 2006: 223). Hifdzu al-bi'ah adalah pemeliharaan dan perlindungan terhadap lingkungan hidup.

Nilai Ketauhidan (keEsaan Allah SWT) adalah prinsip yang menghimpun seluruh manusia kepada Tuhan, adalah dikaitkan dengan pelaksanaan hukum Masjid, masyarakat Sumbawa memandang pelaksanaan hukum adat (hukum Islam) adalah ibadah dalam bentuk penyerahan diri kepada keseluruhan kehendak Allah SWT, sehingga menghendaki dan mengharuskan manusia untuk menetapkan hukum sesuai dengan apa yang diturunkan Allah dan Rasul-Nya. Masyarakat Sumbawa memandang bahwa seluruh semesta alam bersujut pada Allah SWT, dan manusia bagian dari semesta alam harus tunduk pada perintah Allah SWT. Peribadatan dan melaksanakan perintah Allah SWT tidak boleh disepelekan bila mengharapkan kualitas hidup yang penuh Kerik Selamat yaitu keselatan di dunia maupun di aherat, dari lingkup diri (individu), keluarga sampai pada lingkup masyarakat (komunitas) yang lebih luas. 
Ketaatan kepada Allah SWT ini tergambar dari lawas (syair Sumbawa) yang secara tegas mengkonstuksikan muatan kewajiban Boat Aji Ko Nene (yaitu ketaatan dan penyembahan kepada Allah SWT).

\section{Keadilan dan Kebenaran}

Nilai Keadilan, dalam pandangan masyarakat Sumbawa keadilan tidak lepas dari relasi moralitas dan ketauhidan yang berpedoman pada wahyu Allah SWT. Allah SWT sebagai yang Maha Adil, memerintahkan manusia bersikap adil, baik terhadap diri sendiri, orang lain, juga kepada semesta alam (termasuk lingkungan dan hewan). Keadilan adalah sendi pergaulan sosial yang paling fundamental. Jika keadilan dilanggar, sendi-sendi masyarakat akan goyah. Dalam kerik selamat memandang keadilan dalam arti menempatkan suatu pada tempatnya; sama rasa atau sama jumlah; sama lewa (keseimbangan dalam bahasa Sumbawa) bisa berhubungan dengan keseimbangan hak dan kewajiban.

Kemudian yang tidak kalah penting adalah asas kebenaran, yang dalam budaya Sumbawa tercermin dari nilai saling satotang (saling mengingatkan untuk hal kebaikan) dalam hukum masjid, nilai Islam digerakkan untuk merekayasa umat manusia menuju tujuan yang baik dan benar yang dikehendaki oleh Allah SWT. Islam berfungsi sebagai Social Engineering hukum, Nahi Munkar berfungsi sebagai sosial kontrol.

Prinsip ini besar sekali peranan dan faedahnya bagi kehidupan beragama, bermasyarakat, dan bernegara. Baik buruknya kondisi kehidupan tersebut, amat bergantung pada ada tidaknya prinsip inilah menjadi asas penting dalam menilai sebuah kebenaran dalam budaya Sumbawa. Asas keadilan lahir dari persamaan kedudukan dalam masyarakat, baik dalam persamaan menegakkan keadilan yang merupakan keharusan bagi seluruh masyarakat sumbawa, karena Islam mengajarkan untuk berlaku adil.

Adil berasal dari kata 'al-adl' (adil), yang secara harfiah berarti "lurus", "seimbang", sedangkan secara istilah keadilan berarti memperlakukan setiap orang dengan 
prinsip kesetaraan (principle of equal liberty), tanpa diskriminasi berdasarkan perasaan subjektif, perbedaan keturunan, keagamaan, dan status sosial (Yudi Latif, 2011: 111). Adanya aneka kesenjangan yang nyata dalam kehidupan kebangsaan-sebagai warisan dari ketidakadilan, kadilan pemerintahan pra-Indonesia-hendak dikembalikan ke titik berkeseimbangan yang berjalan lurus, dengan mengembangkan perlakuan yang berbeda (The Principle of Difference) sesuai dengan perbedaan kondisi kehidupan setiap orang (kelompok) dalam masyarakat serta dengan cara menyelaraskan antara pemenuhan hak individual dengan penunaian kewajiban sosial.

Komitmen keadilan menurut alam pemikiran Pancasila berdimensi luas. Peran Negara dalam perwujudan keadilan sosial, setidaknya ada dalam kerangka: 1) Perwujudan relasi yang adil di semua tingkat sistem (kemasyarakatan); 2) Pengembangan struktur yang menyediakan kesetaraan kesempatan; 3) Proses fasilitasi akses atas informasi yang diperlukan, layanan yang diperlukan, dan sumber daya yang diperlukan; 4) Dukungan atas partisipasi bermakna atas pengambilan keputusan bagi semua orang. Gagasan keadilan ini juga tidak terbatas pada pemenuhan kesejahteraan yang bersifat ekonomis, tetapi juga terkait dengan usaha emansipasi dalam kerangka pembebasan manusia dari pemberhalaan terhadap benda, pemuliaan martabat kemanusiaan, pemupukan solidaritas kebangsaan, dan penguatan daulat rakyat.

Berdasarkan rumusan Pusat Studi Ekonomi Kerakyatan, Universitas Brawijaya (Pusat Studi Ekonomi Kerakyatan, 2009: 22), keadilan sekurang-kurangnya terwujud dalam tiga bentuk: 1) Keadilan dalam hubungan ekonomi antar manusia secara orang-seorang dengan senantiasa memberikan kepada sesamanya apa yang semestinya diterima sebagai haknya. Inilah yang melahirkan keadilan tukar-menukar; 2) Keadilan dalam hubungan ekonomi antara manusia dengan masyarakatnya, dengan senantiasa memberi dan melaksanakan segala sesuatu yang 
memajukan kemakmuran dan kesejahteraan bersama. Inilah yang melahirkan keadilan sosial; 3) Keadilan dalam hubungan ekonomi antara masyarakat dengan warganya, dengan senantiasa membagi segala kenikmatan dan beban secara merata sesuai dengan sifat dan kapasitasnya masing-masing. Inilah yang melahirkan "keadilan distributif".

Perwujudan keadilan tersebut tidak seharusnya hanya didasarkan pada asas hak dan legal-formal saja, tetapi harus juga dibarengi oleh rasa kasih sayang, dalam hal ini sama dengan nilai saling pedi (saling peduli) dan saling sakiki (saling tolong menolong dalam kesusahan) dalam kerik selamat budaya Sumbawa, yang mengandung semangat kemanusiaan.

\section{Rasional dan bermusyawarah}

Sila keempat Pancasila, "Kerakyatan yang dipimpin oleh hikmat kebijaksanaan dalam permusyawaratan/perwakilan" mengandung beberapa ciri dari alam pemikiran demokrasi di Indonesia, dalam pokok pikiran ketiga dari Pembukaan UUD 1945, disebutkan bahwa kedaulatan itu berdasar atas "kerakyatan" dan "permusyawaratan". Dengan kata lain, demokrasi itu hendaknya mengandung ciri: (1) kerakyatan (daulat rakyat), dan permusyawaratan (kekeluargaan) (Yudi Latif, 2011: 111-112).

Demokrasi permusyawaratan, suatu keputusan politik dikatakan benar jika memenuhi setidaknya empat prasyarat. Pertama, harus didasarkan pada asas rasionalitas dan keadilan bukan hanya berdasarkan subjektivitas ideologis dan kepentingan. Kedua didedikasikan bagi kepentingan banyak orang, bukan demi kepentingan perseorangan atau golongan. Ketiga, berorientasi jauh kedepan, bukan demi kepentingan jangka pendek melalui akomodasi transaksional yang bersifat destruktif (toleransi negatif). Keempat, bersifat imparsial, dengan melibatkan dan mempertimbangkan yang dapat menangkal dikte-dikte minoritas elite penguasa dan pengusaha serta klaimklaim mayoritas.

Tentang bagaimana cara bekerjanya demokrasi 
permusyawaratan, Hatta menganjurkan perlunya berjejak pada tradisi permusyawaratan desa. Meski demikian, dia mengingatkan bahwa tidak semuanya yang tampak bagus pada demokrasi desa bisa dipakai begitu saja pada tingkat negara. "Mufakat yang dipraktikkan di desa-desa dengan cara mengambil keputusan dengan kata sepakat, dengan persetujuan semuanya, setelah masalahnya diperbincangkan dengan panjang lebar. Adapun pada tingkat negara, terdapat berbagai partai dan pertentangan politik, sehingga putusan dengan mufakat secara bulat memang sulit dicapai dalam Dewan Perwakilan Rakyat. Oleh karena itu, sebagai pilihan terakhir, harus dimungkinkan pengambilan keputusan dengan suara terbanyak. Berkaitan dengan itu, Hatta menegaskan bahwa mufakat yang dipaksakan sebagaimana lazim terjadi di negeri-negeri totaliter tidaklah sesuai dengan paham demokrasi Indonesia, sebab mufakat baru jadi sebagai hasil dari pada permusyawaratan, jika tidak ada musyawarah dimana tiap-tiap orang berhak untuk menyatakan pendapatnya, maka tidak ada mufakat pula.

Asas musyakara (Musyawarah) dalam falsafah Sumbawa selalu digunakan oleh masyarakat Sumbawa dalam memutuskan seluruh permasalahan yang ada di dalam masyarakat Sumbawa, dengan menjunjung tinggi nilai-nilai kekeluargaan, nilai saling menghormati, nilai kebenaran dan nilai musyawarah dan mufakat, yang diayomi dengan nilai Ketauhitan akan kekuasaan Allah SWT sebagai pemilik semesta alam dan kehidupan ini. Sehingga dalam memutuskan segala permasalahan yang ada di dalam masyarakat selalu menggunakan metode dan cara yang islami yaitu dengan musyakara (musyawarah dalam bahasa Sumbawa).

Musyakara ini adalah pengambilan keputusan terbaik dalam masyarakat Sumbawa, yang mana dalam musyakara masalah dibedah secara logis dan terbuka dengan pola komunikasi yang efektif, dengan jalan dialogis yang terbuka bagi seluruh anggota masyarakat serta mengedepankan 
nilai-nilai kebenaran, karena musyawarah ini bertujuan untuk mencari akar masalah, memecahkannya secara logis dan bertnggung jawab, kemudian dicari sumber rujukan dalam Al-Qur'an dan Al-hadist serta budaya dan adat istiadat Sumbawa, dari itu semua maka di putuskanlah putusan yang terbaik untuk seluruh anggota masyarakat.

Nilai-nilai Ketuhanan yang dikehendaki Pancasila adalah nilai Ketuhanan yang positif, yang digali dari nilai-nilai profetis agama-agama yang bersifat inklusif, membebaskan, memuliakan keadilan dan persaudaraan. Ketuhanan yang lapang dan toleran yang memberi semangat kegotong-royongan dalam rangka pengisian etika sosial dalam kehidupan berbangsa dan bernegara. Dengan penempatan sila Ketuhanan di atas sila-sila yang lain, politik negara mendapat akar kerohanian dan dasar moral yang kuat dan menjadi dasar menuju jalan kebenaran, keadilan, kebaikan, kejujuran, dan persaudaraan. Sila Ketuhanan memberikan dimensi agama pada kehidupan politik serta mempertemukan dalam hubungan simbiosis antara konsepsi "daulat Tuhan" dan "daulat rakyat", yang disebut oleh Sartono Kartodirdjo dan Kuntowijoyo sebagai "teodemokrasi".

Demokrasi yang berketuhanan, kekuasaan diletakkan di bawah Tuhan dan rakyat. Menurut Kuntowijoyo, Tuhan dan manusia harus dibaca dengan "satu" tarikan napas, karena itu ditulis dengan "teodemokrasi". Berarti bahwa kekuasaan manusia adalah amanah Tuhan yang harus diemban dengan sungguh-sungguh. Manusia tidak boleh bermain-main dengan kekuasaan itu, dalam demokrasi modern, hal ini selaras dengan konsep tanggung jawab dan transparansi. Konsep accountability di hadapan Tuhan Yang Maha ini harus disadari oleh setiap orang supaya orang tidak melalaikan tugastugas kekuasaannya, untuk mencegah terjadinya penyalahgunaan kekuasaan atas nama Tuhan dengan mengembangkan demokrasi. Sebelum ada konsep demokrasi, tanggung jawab itu hanya kepada Tuhan. Sejarah Jawa, raja bergelar 
khalifatullah, dan dalam sistem pengetahuan rakyat, kekuasaan raja memang dianggap sebagai kekuasaan Tuhan yang tidak bisa diganggugugat karena itu raja bisa bertindak sewenang-wenang.

Konsep Teo-demokrasi, kekuasaan itu dibatasi oleh rakyat. Kekuasaan itu juga diawasi oleh rakyat, disamping diawasi oleh Tuhan, sehingga kekuasaan menjadi transparan, bukan sesuatu yang ajaib, sehingga dianggap steril dari kontrol dan pengawasan. Panduan nilai-nilai Ketuhanan, Pancasila bisa memberikan landasan moral dan filosofis bagi sistem demokrasi yang hendak dikembangkan (Yudi Latif, 2011: 111-113).

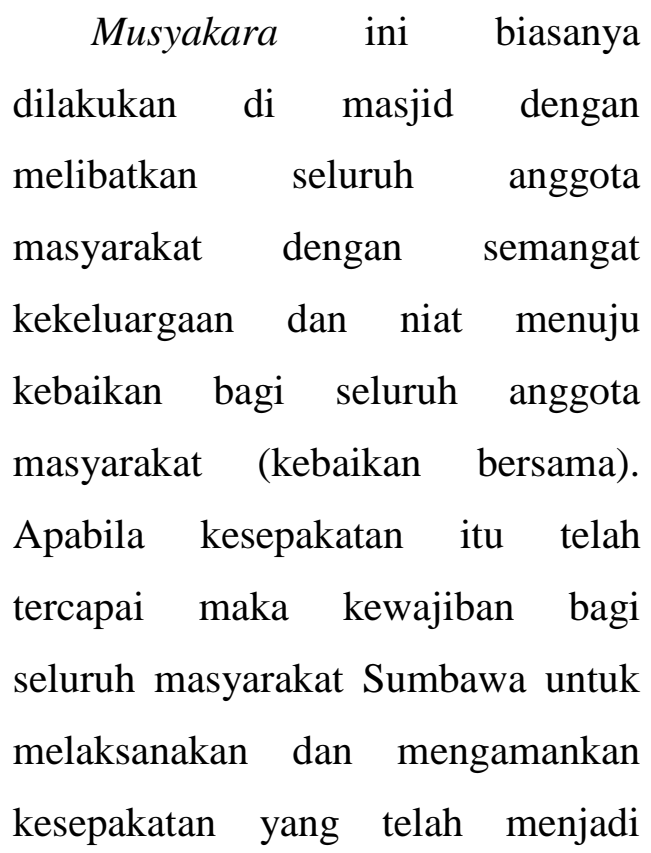

konsensus bersama, dalam budaya Sumbawa kesepakatan hukumnya sama dengan janji yang harus dilaksanakan oleh pembuat janji, karena menurut masyrakat Sumbawa dengan nilai Kerik Salamat bahwa manusia beradab atau masyarakat beradab adalah manusia yang menepati janji (amanah). Melanggar janji merupakan satu tanda dari kemunafikan. Nabi SAW bersabda: "Tanda orang munafik itu ada tiga; bila berbicara dia berbohong, bila berjanji dia melanggarnya dan bila diberi amanat dia mengkhianatinya".

\section{Saling menghormati dan memulyakan}

Asas falsafah saling satingi (saling menghormati dan memuliakan) yang merupakan nilai dalam Islam yang sudah menjadi bagian dari budaya Sumbawa, mengajarkan untuk menghormati antar sesama manusia walaupun telah menjadi mayat. Sehingga saling satingi ini menjadi penting dalam setiap aktivitas keseharian masyarakat Sumbawa, contohnya dalam menentukan putusan atas setiap permasalahan yang ada dalam 
masyarakat, baik itu masalah publik maupun masalah privat, yang dalam masyarakat Sumbawa semua masalah perlu dibicarakan/rembuk secara bersama-sama sebagai bukti saling menghormati dalam budaya Sumbawa.

Budaya yang mengatur kepentingan umum, misalnya menentukan pola pemeliharaan lahan dan pengawasan hewan ternak, ini dilakukan dengan musyawarah dalam semangat saling menghormati dan memuliakan, kemudian dalam hal privat yaitu cara perkawinan dalam adat Sumbawa pasti dibutuhkan musyawarah untuk menentukan kapan dan bagaimana proses perkawinan yang akan dilangsungkan, yaitu terlihat dari aktifitas saling menginformasikan dan memohon petunjuk kepada kaum kerabat tentang sesuatu masalah "pasamada dan parajak" disitulah letak posisi kita saling satingi karena penghormatan kita dalam keluarga yang diakui oleh budaya kita orang Sumbawa.

Saling satingi (penghormatan) dan kekerabatan terletak pada semua orang Sumbawa sehingga tidak ada perbedaan diantara anggota masyarakat Sumbawa, baik itu kaya maupun miskin. Yang membedakan kita hanya tingkat keimanan dan ketaqwaan kepada Allah SWT. Status ekonomi tidak dipakai dalam budaya Samawa, semakin tinggi kita saling satingi maka semakin tinggi posisi pada diri kita sendiri. Nilai saling satingi sebagai bagian dari memuliakan manusia.

\section{Gotong royong dan Kekeluargaan}

Asas kekeluargaan bukanlah asas keluarga atau asas kekerabatan (bukan family system atau kinship) yang nepotis. Asas kekeluargaan adalah kebersamaan dan kekeluargaan. Asas kekeluargaan adalah satu kesatuan dengan asas kebersamaan yang tidak dapat di pisahkan satu sama lain, asas ini harus pula disertai dengan emansipasi dan partisipasi, sehingga kekeluargaan dan kebersamaan menjadi dasar bagi partisipasi dan asas kekeluargaan menjadi dasar bagi emansipasi, tidak akan ada partisipasi tanpa adanya emansipasi (Sri Edi Swasono, 1997). Asas kekeluargaan juga harus ditopang 
dengan nilai saling tulung (saling tolong menolong dan gotong royong), ini merupakan tindak lanjut yang nyata sebagai prinsip hidup masyarakat Sumbawa dalam membantu sesama, saling menolong dan gotong royong sesuai dengan tradisi bangsa Indonesia pada umumnya.

Nilai toleransi, ini menekankan masyarakat Sumbawa untuk hidup rukun dan damai atas perbedaan yang ada, baik itu perbedaan pendapat dan cara pandang maupun yang lain. Berangkat dari latar belakang kebudayan yang majemuk sehingga tercipta rasa egaliterian/persamaan antar anggota masyarakat Sumbawa. Secara garis besar, dapat dikatakan bahwa kerajaan/kesultanan yang di wilayah Sumbawa dipengaruhi oleh budaya luar, seperti yang telah diulas pada bagian "peta kehidupan keberagaman". Nilai dan semangat persamaan menjadi tumpuan bangunan hukum masjid ialah bahwa semua anggota masyarakat mempunyai hak yang sama di hadapan hukum, persamaan ini menebus batas kaya dan miskin, pemimpin dan rakyat, Mereka semua sama sederajat atau sama tingkatan, tanpa memandang warna kulit dan suku-bahasa.

Persamaan ini akan terwujud jika terjalin hubungan persaudaraan, semakin banyak persamaan, semakin kokoh pula persaudaraan. Persamaan rasa dan cita merupakan faktor dominan yang mendahului lahirnya persaudaraan hakiki, dan pada akhirnya menjadikan seorang merasakan penderitaan derita saudaranya (saling sakiki), mengulurkan tangan sebelum diminta serta memerlukan sesamanya bukan atas dasar memberi dan menerima (saling tulung), mengutamakan orang lain atas diri mereka, walaupun diri mereka sendiri kekurangan (saling angkat).

\section{Kesimpulan}

Pembangunan hukum merupakan alat untuk melakukan perubahan sosial, itu perlu dipikirkan pembangunan hukum alternatif yang mengedepankan nilai lokal yang dilaksanakan secara demokrasi dengan mekanisme permusyawaratan dengan empat prasyarat. Pertama, 
harus didasarkan pada asas rasionalitas dan keadilan bukan hanya berdasarkan subjektivitas ideologis dan kepentingan. Kedua didedikasikan bagi kepentingan banyak orang, bukan demi kepentingan perseorangan atau golongan dalam bingkai persahabatan dan saling tolong menolong. Ketiga, berorientasi jauh kedepan, bukan demi kepentingan jangka pendek melalui akomodasi transaksional yang bersifat destruktif (toleransi negatif). Keempat, bersifat imparsial, kebersamaan dan saling menghormati yang bertujuaan dapat menangkal dikte-dikte minoritas elite penguasa dan pengusaha serta klaimklaim mayoritas. Konsep Teodemokrasi dalam nilai kearipan lokal kerik salamat masyarakat Sumbawa, memandang bahwa kekuasaan itu dibatasi oleh rakyat, kekuasaan itu juga diawasi oleh rakyat, disamping itu juga diawasi oleh Tuhan, sehingga kekuasaan menjadi transparan, bukan sesuatu yang ajaib, sehingga dianggap steril dari kontrol dan pengawasan. Panduan nilai-nilai Ketuhanan dalam kerik salamat dan Pancasila bisa memberikan landasan moral dan filosofis bagi sistem demokrasi dan pembangun hukum yang rasonal, adil dan bermoral bagi masyarakat Sumbawa. Hal ini bisa menjadi model formulasi hukum bagi daerah (produk hukum daerah) lain termasuk juga dalam pembuatan undang-undang dalam sekala nasional.

\section{Daftar Rujukan}

Ali Yafie. 2006. Merintis Fikih Lingkungan Hidup. Jakarta: UFUK Press.

Budiono Kosumohamidjoyo. 2000. Kebinekaan Masyarakat Indonesia, Suatu Problematika Filsafat Kebudayaan. Jakarta: PT Grasindo.

Dedy Ismatullah. 2003. Gagasan Pemerintahan dalam Konstitusi Madinah di Tinjau dari Prinsip-prinsip Negara Hukum. Bandung: UNPAD

M. Pobattingi. Relevansi dan Masalah Nasionalisme. Jurnal Ilmu Politik. No 16. 1998.

Otje Salman dan A.F. Susanto. 2008. Teori Hukum: Mengingat, Mengumpulkan dan Membuka Kembali. Bandung: Refika Aditama.

Pusat Studi Ekonomi Kerakyatan. 2009. Ekonomi Kerakyatan, Malang: Universitas Brawijaya.

Samuel Huntington. 1995. Gelombang Demokrasi 
Ketiga, edisi terjemahan.

Jakarta: Grafiti.

Sanapiah S Faisal. 1999. Budaya

Kerja Masyarakat Pertani

Sumbawa; Kajian

Strukturasionistik: Kasus

Petani Sumbawa. Surabaya:

Disertasi Program

pascasarjana Universitas

Airlangga.

Sri Edi Swasono. 1997. Pasar-Bebas

yang Imajiner: Distorsi

Politik dan Pertentangan

Kepentingan Internasional.

Majalah Kliping.

Wolfang Friedmann. 1996. Teori dan Filsafat Hukum, Telaah Kritis atas Teori-teori Hukum, jilid II, Terjemahan Mohammad Arifin dari Legal Thoery. Jakarta: Raja Rgafindo Persada.

Yudi Latif. 2011. Negara Paripurna: Historisitas, Rasionalitas dan Aktualitas Pancasila. Jakarta: Gramedia Pustaka Utama. 